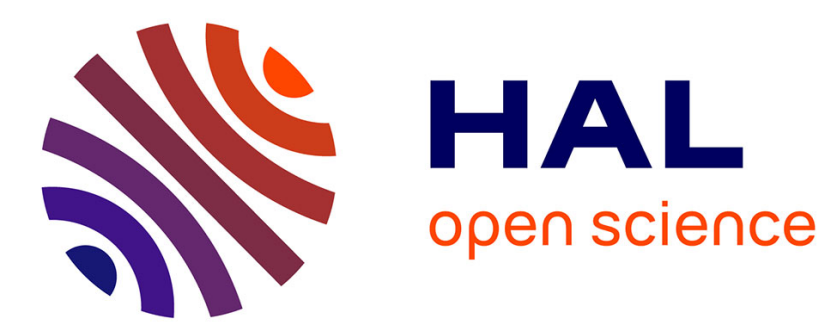

\title{
"We were like cartographers, mapping the city": An interview with Arvind Krishna Mehrotra
}

Laetitia Zecchini

\section{To cite this version:}

Laetitia Zecchini. "We were like cartographers, mapping the city": An interview with Arvind Krishna Mehrotra. Journal of Postcolonial Writing, 2017, 53 (1-2), pp.191-207. 10.1017/CBO9781139940887 . hal-01597698

\section{HAL Id: hal-01597698 \\ https://hal.science/hal-01597698}

Submitted on 15 Mar 2023

HAL is a multi-disciplinary open access archive for the deposit and dissemination of scientific research documents, whether they are published or not. The documents may come from teaching and research institutions in France or abroad, or from public or private research centers.
L'archive ouverte pluridisciplinaire HAL, est destinée au dépôt et à la diffusion de documents scientifiques de niveau recherche, publiés ou non, émanant des établissements d'enseignement et de recherche français ou étrangers, des laboratoires publics ou privés. 


\title{
"We were like cartographers, mapping the city": An interview with Arvind Krishna Mehrotra
}

\author{
Laetitia Zecchini
}

\section{ABSTRACT}

Arvind Krishna Mehrotra is one of the most distinguished "Bombay poets", whose career spans six decades, from his first work Bharatmata: A Prayer (1966) brought out by the Ezra-Fakir Press he founded to his recently published Collected Poems 1969-2014. His contribution to the Indian English language tradition has been far-reaching, not only through his poetry itself, but through his role as translator, anthologist, editor and critic. In this interview, conducted on April 2021,2016 , Mehrotra ranges over his extensive career, reflecting on the transnational web of genealogies, associations and translations that lie behind an "Indian poem", on his friendship and artistic collaborations with Arun Kolatkar, Adil Jussawalla and A.K. Ramanujan, on the break that Indian writers and artists of his generation were trying to make, and on the way his own poetry was inspired by the American Beats. He also discusses his role in the little magazine/small press movement of the 1960s and 1970s when he edited ezra and damn you: a magazine of the arts, and co-founded the Clearing House collective.
Bombay/Mumbai; Indian poetry in English; little magazines; The Beats; Arun Kolatkar; modernism; Nissim Ezekiel

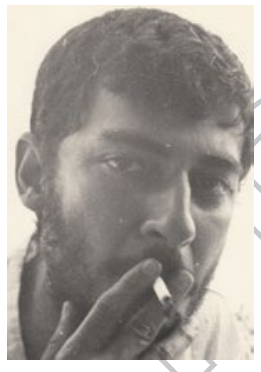

Arvind Krishna Mehrotra was described by his close friend and fellow poet Adil Jussawalla as the "firebrand" of the poetry scene in the 1960s and 1970s (Kohli 1991, 139). A key figure of the little magazine/small press movement, whose poems first appeared in Indian and American little magazines, he published four collections of poetry and recently brought out his Collected Poems 1969-2014 (Mehrotra 2014). He is also an incisive critical voice, whose editions, anthologies and essays, such as The Oxford India Anthology of Twelve Modern Poets (Mehrotra 1992), The Illustrated History of Indian Literature in English (Mehrotra 2003) or Partial Recall: Essays on Literature and Literary History (Mehrotra 2012), have been instrumental in shaping the field of Indian poetry in English and forcing us to revise the obvious cartographies and linear genealogies of what is commonly known as "Indian literature". The Absent Traveller, his translations of Prakrit love poetry from the 2nd century AD (Mehrotra 1991) and Songs of Kabir, his "recastings" of Kabir (Mehrotra 2011), are recognized as classics. 
For a writer who lives between Allahabad and Dehradun - two places that feature prominently in his poetry - but who fancied himself to be a Lower East Side poet in the 1960s and 1970 s and also calls himself a "Bombay poet"; who once acknowledged that "to a poem, the location - whether cultural, historical, geographical or fictive - is everything" (Mehrotra $2012,168)$, the question of belonging, the location of literature and the geography of letters are crucial preoccupations. In his preface to the Oxford anthology, Arvind Krishna Mehrotra describes himself and other poets of his generation writing in English as "earlier strugglers in the desert". Something of that struggle comes through in the conversation below, which also illuminates the vital bonds of friendship that connected many of the "Bombay poets" to each other, and the unpredictable connections and constellations that make up the worlds of "Bombay poetry". As marginal, eccentric or off-centre as the Indian little magazines of the 1960s seemed to be, they travelled to different worlds, especially to America. And as some of Arvind Krishna Mehrotra's statements from the magazines damn you or ezra reproduced below demonstrate (see Figures 1 and 2), they also helped forge countercultural affiliations and transnational conspiracies of "anti-poets". The "worlds of Bombay poetry" are also those of world literature, worlds imagined and reclaimed by Arvind Krishna Mehrotra and writers of his generation - all "bulimic" readers of literature in translation - as their own. The Gujarati poet Prabodh Parikh (b. 1945) remembers that the books arriving at the iconic Bombay bookshop Strand Book Stall were enough for him to imagine conversing with André Breton or Jean-Luc Godard: "We were intoxicated by imaginary homelands" ([1996] 2006, para. 5). And Arvind Krishna Mehrotra famously acknowledged that ever since he was 17 years old, he had harboured the illusion that he did not live in Uttar Pradesh but in New York (Mehrotra 2012, 113). New York, Iowa and Allahabad, Douglas Blazek, Allen Ginsberg and Lawrence Ferlinghetti, Jacques Prévert and Guillaume Apollinaire, Bhupen Khakhar, Gulammohammed Sheikh and the central figures of Arun Kolatkar, A.K. Ramanujan and Adil Jussawalla all make up the worlds of Arvind Krishna Mehrotra's poetry and his Bombay.

Laetitia Zecchini (LZ): You have described your boyhood as uneventful, in a family that wasn't particularly literary. But you were "saved" after high school by the book-lined study of your uncle in Allahabad, by your friendship with Amit and Alok Rai, and by their uncle, Vijay Chauhan, who lived in New York and sent them copies of Village Voice. I wonder if you could tell us about the person you were at 16 or 17 , and what it was like to discover these American magazines with poems like Ferlinghetti's "Underwear" or Ginsberg's "America".

Arvind Krishna Mehrotra (AKM): When I began writing at 17 there was no literature I knew that I could relate to, but then again I had not read very much poetry, except what was to be found in school and intermediate college textbooks. So the early poems were written in a vacuum, from a non-literary space. I was writing because words came to me and I liked the linear patterns the Royal typewriter made on the page. I was then living with my uncle in Allahabad and spent a lot of time looking at the bookshelves in his library, desiring to be a book myself or at least to write one. I was 18 when in August 1965 I bought Penguin Modern Poets 5 (Ferlinghetti, Ginsberg, and Corso 1963), which had the Ferlinghetti and Ginsberg poems you mention. Gregory Corso was the third poet in it. Reading them after, say, "The Solitary Reaper", was a new experience. So the new experience was of writing that was not of India. It was the American Beats. Poets usually grow up reading their own literatures 


\section{statement}

not the organ of a hungry generation, a clan if anti-poets, or a writer's workship. not the publie child of a bombay professor. we are illiterates. unaware of ists/isms. If we tind, a liberated scin on a creative adventure we might joli him. we might let him go his way. ve are not pamph.eteers/journalists/hackwriters. not even poets/painters/seers. we are men, breathing. and we breatine for ourselves. not for the 'age ve live in'. still, somevhere between an angel and a He-llan lives a magasine of the arts. its open peges greeting boto urinal and fountain. vearing the lunes outside, and a kidneyfountain. vearing the lunes outside, and a kidneycap. the Directory or Little lagazines lists DY as from from India". with our rewarós being spiritual, we needn't go to swami mahesh yogi to communicate with the inner ocean of piss.

a mag which gets out two issoos, survives the d sbacle, and goes on to a third foumth fifth can go on to a hundred. and now its time to solióify our position. dig in. wake zigzag trenches. fire back. oil and set the mimeowachine like a machinegun.

creation is aone when a pair of red hands tap an insane brain. when a crow in flitat scratches its paws over a desert its a canves we try to get hold cf, before wind and sand pile in. we selvage literature from little known little people, making sporadic and silent appearances. ve're on the prowl.

fuque politiques. DY has nothing to do with collapsible governments. ken geering, ed. of breakthru, thinks we are yankee oriented, a yanken, eric oatman, who edits the manhattan review, writes "the name is too damn british". ana so, we like to keep them puessin and leave the capitals of the skyscraping earth' tc decice enongst themselves.

over the months. DY and ezra-fakdr press have collected the wine and oll antho which has so many eds of littles from all over - and only them. we are trying to get out this srectal number, bit cant say when; a lot derends on our being abla to find the right patrons - whom wa are shamel sssly searching $f$ or. wo are now in no position to mak.s promisas about any future numbers, but that there will ba more is as certain as saying there will be more rain. whoever is interested in seeing more of us should try to contribute, preferably in eash, and then cross $h / s$ thumbs and rait. its a confession we have to make against our wishes, that DY is. among, ever 500 million people, the only mag siven to tha arte. 


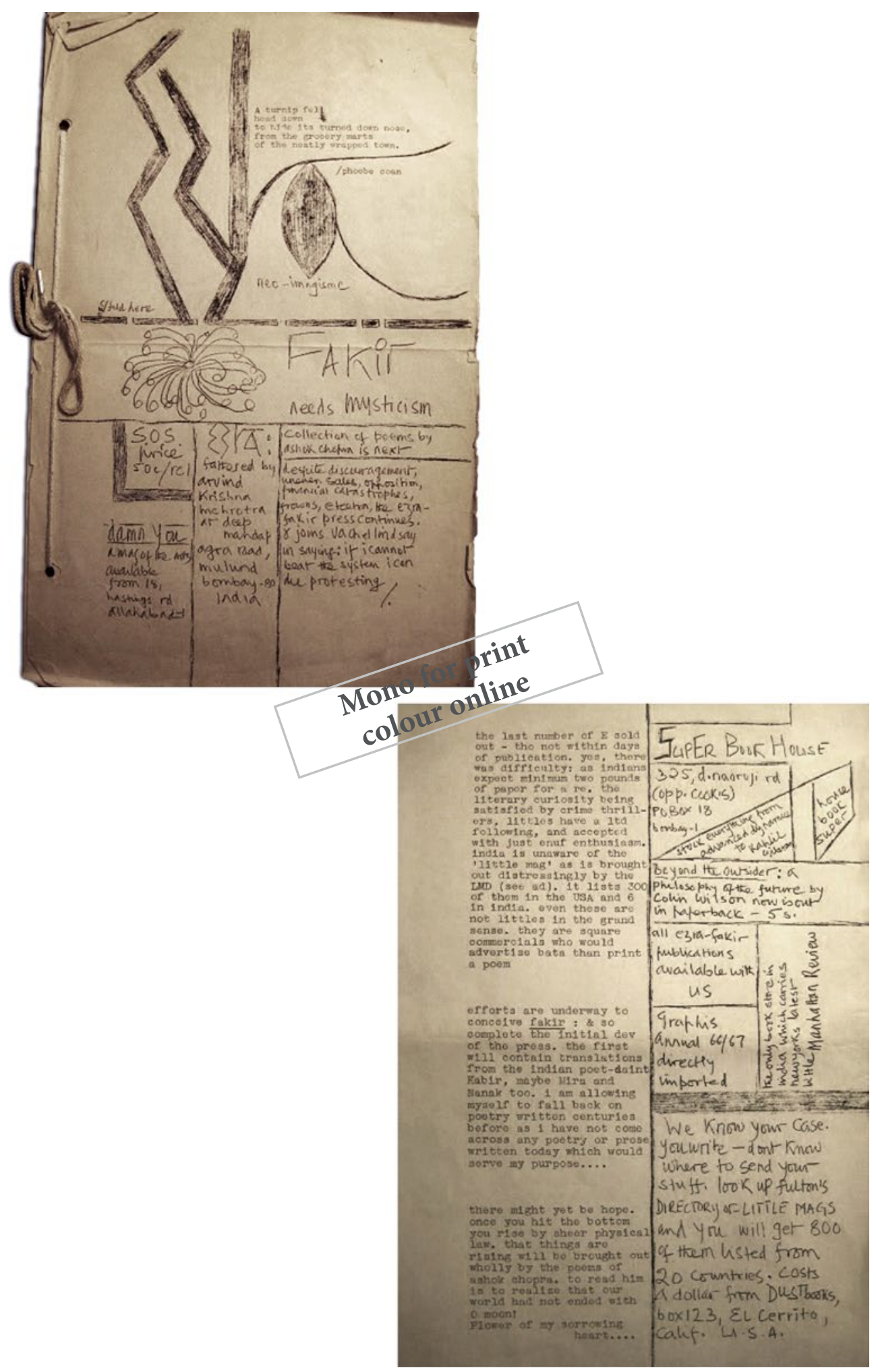

Finure ). (nver and last nace of ezra ) (Mehrotra 1967)

This is a draft version and additional corrections may have been inserted at a later stage.

Please check the final published manuscript online: http://www.tandfonline.com/toc/ripw20/53/1-2 
and the writing done in their own languages. But I began writing in English in Allahabad in 1964-65. I suppose it would have been different had I been writing in Hindi."Go fuck yourself with your atom bomb", Ginsberg says in "America”. Now if an American poet could say this of America and its bomb, I could certainly say it of India, though at that time India was far from having a bomb. Out of some such mix of youth, rebellion and Beat poetry came "Bharatmata" (Mehrotra 1966), ${ }^{1}$ which I meant entirely ironically, comparing India to a lavatory in the world's slum. It drew on the spirit of the anti-nationalist poem. Although there is in "Bharatmata" a sense of belonging, the belonging is to the two cities in the poem (Bombay, Bhilai), not country (India). Bhilai is where my father worked and where I did some of my schooling. Ginsberg purged me of all nationalist feelings. It's good to rail against your country, he seemed to be telling me. In any case, when you are 18 and full of sexual yearning, patriotism is the last thing on your mind. I disliked marching in school and later at university, where the National Cadet Corps was compulsory. I was frequently out of step and shunted off to rear of the unit.

\section{LZ: And yet I imagine that post-Independence India was all about cultural national- ism, about fashioning a national language, a national culture . .}

AKM: I was born in the year of Independence, so the nation-building project, for me, was a very tangible thing. In Bhilai there was a steel plant being built with Russian aid. It was one of Nehru's temples of modern India, a part of the five-year Plans, which were modelled on the Soviet system. You went to a non-private school where the children of the workers also went. Education was free and you got a banana and two slices of buttered bread for your midday meal. So you grew up in an egalitarian community which I suppose believed in Nehru's vision, or was a product of it. I did not of course comprehend much of what was going on. All I knew was that the president of India at the time, Rajendra Prasad, had visited Bhilai to inaugurate the first blast furnace. This was in 1959, and there was a big fuss about it. But the idea that here, before my eyes, was a nation being built brick by brick and blast furnace by blast furnace, had not sunk in. Cultural nationalism was short-circuited by the discovery of the Beats and my own disinterest in political ideologies. The Beats introduced me to the idea that the language of poetry is not very different from the language of everyday speech, by which I mean our everyday English speech in Allahabad. And that words of abuse, references to the quotidian, and irreverence were part of it. Along with irreverence towards country came irreverence towards bourgeois society (Corso's "Marriage") and towards religion (Ferlinghettis "Underwear": "The Pope wears underwear I hope"). When Amit Rai and Ifirst read these poems as teenagers we couldn't stop laughing. "Women's underwear holds things up / Men's underwear holds things down”. Poetry was fun, as Wordsworth and Tennyson could never be. In poetry you could think the unthinkable and say it. I began to associate it with transgression.

Unknown to me, in Bombay in 1965, Arun Kolatkar, whom I had then not heard of, had already put out his poetic manifesto, without of course calling it that. These were the found poems in Bombay-Hindi, whose English title is "Three Cups of Tea”. Here was the poetry of the street in the language of the street, which could only be translated not in Bombay English but in the American idiom. Though it did not come about by design, in the 1960s a new generation of Indian poets in English had arrived, the first after Independence, and they were constellated in Bombay. What marked them out as a generation was, broadly speaking, a common aesthetic. 
To come back, the issues of the Village Voice and the discovery of the Beats led the three of us, Amit Rai, Alok Rai and myself, to start damn you in Allahabad. As you can see from its six issues, and also from ezra, the idea was not only to publish poets from within the country - in the beginning we didn't know who the Indian poets were anyway - but also from abroad (see Figures 1 and 2). Word of us spread on the little magazine grapevine and soon we had people from England and the US sending us their poems. One of them was Douglas Blazek.

I did not then know that Ginsberg had come to India and gone. I was too young, maybe 14 or 15 at the time. Arun Kolatkar, who was much older, got to know Ginsberg quite well and they remained friends. I may not have registered Ginsberg's India visit, yet the imagination sloped towards some kind of internationalism. It took me a while to see myself as an Indian poet. One was living in India, but in one's head one was living somewhere else.

LZ: Do you think it's possible to say that you are actually much more "worldly" from Allahabad or from Dehradun than you could have been at the alleged center of the literary world? As if it was from the so-called "margin" or from the "outside" that you could speak to, or rather with, the world. I mean, you chose to stay in Allahabad . . .

AKM: You know, Laetitia, the categories of "marginality" and "centre" did not exist in the 1960s the way they do now. Moreover, no one consciously sets out to be marginal. Had I stayed on in America I would have been marginal in a much more severe way than I ever could be in Allahabad, even though I was writing in English, a language which, in the India of the 1960s, looked like it was on its way out. In Iowa City I found myself often writing about Allahabad. In the poem "Continuities" I mentioned the musical names of its roads - Thornhill, Hastings, Lytton - feeling nostalgic for home. Somewhere along the line I realized that if I was going to write about Allahabad in Iowa City, then I may as well do so in Allahabad. Since I draw my poetic sustenance from the things around me, the bountiful goods of America, paradoxically, left me feeling starved.

LZ: Sorry to interrupt, Arvind, but when you left for Iowa City did you know that it was going to be for two years? Did you not consider the possibility of extending your visit and perhaps of staying on in America?

AKM: The University of Iowa's International Writing Program, for which I had gone, was for nine months but at the end of it, in the summer of 1972, I did not really want to come back. I knew that once I returned to India I would not have the opportunity to travel again any time soon. It was hugely difficult to get out of the country in the 1970s, unless you opted for an academic programme like a $\mathrm{PhD}$. And I did not want to do that. So I asked Paul Engle, the Program's director, if there was any way in which he could help me extend my stay, and he suggested that I take up an assistantship. That's how I got to spend two years in Iowa. In my second year I sat for the GRE [Graduate Record Examination] in order to become a grad student, and paid in-state tuition, which was not very much, so it all worked out. I attended the Translation Workshop and took a course in typography, but wrote no papers or gave any exam. After the second year was over I packed my bags and left.

It never even struck me that I should continue to live in the US, beyond the two years I was there. Among other things, I had a permanent job back in Allahabad, and I was on leave from the university. There were other reasons too, equally compelling. It is one thing to imagine from Allahabad that you're living in the US but quite another to be actually living there. As I discovered, it's easy to be an American poet in India but much harder to be an This is a draft version and additional corrections may have been inserted at a later stage. Please check the final published manuscript online: http://www.tandfonline.com/toc/rjpw20/53/1-2 
American poet in America. It would have meant starting the poetic journey all over again, this time from the cornfields of the Midwest, and at 26 I was not ready to do it.

Moreover, what would I write about? I could not respond to the American landscape or place names, to its trees or cities. Expatriate writers, whether it's Ved Mehta, Salman Rushdie, Rohinton Mistry or A.K. Ramanujan, mostly write about the places they came from. I felt I could not become one of them. It may simply be a question of temperament. In Iowa City I got to know a very fine poet, and now largely forgotten, G.S. Sharat Chandra. He was from Bangalore and had done his MFA [Master of Fine Arts] in Iowa, but despite many years of living in the US he felt he had not been sufficiently recognized. He would have liked to return to India, I think, but never could.

Before I returned to India in September 1973, Paul Engle had asked me to edit an anthology of modern Indian poetry for a series to be published by the University of Iowa Press. So I had a "project" to work on. That same year, when I went to Bombay, I told Arun [Kolatkar] about it and asked him if he had written anything new. Arun said he had been thinking of something, but didn't say much more. I had no idea what to expect. Then in January or February 1974, quite out of the blue, there arrived Kolatkar's Vejuri typescript. Adil Jussawalla had been working on the poems in Missing Person (Jussawalla 1976) and Gieve Patel too had a manuscript. I had the poems I'd been writing in Iowa City, which included "Continuities". And so the idea of Clearing House was born.

LZ: So Clearing House finds its origins in the failed project of the Iowa anthology!

AKM: Well Jejuri must have been on Arun's mind for a while. It may be that asking him to contribute to the anthology hastened the writing, though Arun was never someone who could be hastened.

LZ: Why did the Iowa anthology not see the light of day, and was your OUP [Oxford University Press] anthology, Twelve Modern Indian Poets (Mehrotra 1992), a kind of follow-up of that first project?

AKM: You see, Laetitia, from Iowa an anthology of Indian poetry from the major Indian languages seemed possible to do. The library was excellent, as American university libraries generally are, and there were Xerox machines everywhere. But once I returned to India, everything looked much more difficult. More than anything else, there was no advance and no money to travel.

\section{LZ: Oh, so it was to be an anthology of Indian poetry from all modern Indian languages?}

35 AKM: Yes. A bit like Adil's New Writing in India (Jussawalla 1974), though his included prose as well. Actually this morning I sent Adil a copy of the letter that he'd written me in 1969, when he was planning the Penguin anthology. But I couldn't have done the Iowa book. The project fell through and I was happy to let it go. By then we had also started talking about Clearing House. When I came back to India in 1973, my head was full of the

40 little magazine/small press scene in the US. It was exciting to think that we, in India, might actually have one of our own.

LZ: Going back to the issue of Bombay and belonging, I thought we could reflect on the fact that you call yourself a "Bombay poet" when you only lived in the city for two years as a student. 
AKM: Since there's nothing known as an "Allahabad poet", "Bombay poet" was a nice identity to have! But it was really about being associated with a group of poets. And we did a lot of work together. I can't see myself having any other literary identity. On the subject of "Bombay poets", we all had a different relationship with [Nissim] Ezekiel. Arun had known Ezekiel from the very beginning. His first published poem in English appeared in the inaugural issue of Quest in 1955, ${ }^{2}$ and Gieve's first book of poems called Poems (Patel 1966) was brought out by Nissim - the only book Nissim ever published. But as I was telling Adil only last week, for me Nissim was someone to rebel against.

\section{LZ: You once declared that $\mathbf{1 0 0}$ years should have separated Ezekiel and Kolatkar.}

10 AKM: I did feel this because they came at the world and at language from what seem like opposite directions, but they were born just seven years apart. I never felt any closeness to Ezekiel. ${ }^{3}$ Now I can see what he was doing, breaking out of the dead end that Sri Aurobindo and Sarojini Naidu had got Indian poetry in English into. In the 1950s he would have felt quite alone. There was no one he could have shared anything with. He was trying to arrive at that very flat language...

\section{LZ: And at a colloquial idiom ...}

AKM: Yes, trying to get away from the divine abstractions of Sri Aurobindo and the ethnographic verses of Sarojini Naidu. "Bharatmata" appeared in 1966 when I was still a student in Bombay. I can't remember where I ran into Nissim, but I gave him a copy of the poem, probably sold it to him for 50 paisa, which was the price. A month or two later, to my surprise, I got a postcard saying that he would like to print the poem in Poetry India. Now "Bharatmata" was everything that Nissim's poetry was not, but he liked it enough to offer publication in his magazine. It says something about him and his openness to different kinds of verse. It was a huge moment for me.

LZ: You, Arun Kolatkar and Dilip Chitre were influenced by the surrealists, the Beats and the whole American counterculture, while Nissim seemed more into British poetry.

AKM: Very much so. In 1966 he represented the enemy, so to speak. But he was also the first modern poet to come up with memorable lines like "My backward place is where I am" from "Background, Casually" (Ezekiel 2005, 181). This was something you came to appreciate only later.

\section{LZ: So, Arvind, you arrived in Bombay in 1966 when you were 19 years old. What do you remember of the city at that time?}

AKM: What I remember, Laetitia, is what any young person going from a place like Allahabad to a big city like Bombay remembers, which is a great sense of estrangement. I often said to myself that were I to fall off the local train in an accident, no one will know who I am, even notice my absence. I lived in Mulund in the house of a lady my parents looked upon as their guru. I once even tried to run away from there and go back to Allahabad. Without damn you and ezra, which I would carry around in a blue overnight case, trying to peddle them, the loneliness would have been worse. Otherwise, of the cultural life of the city, one remembers Samovar, the café in the Jehangir Art Gallery, where I mostly hung out, and the magazines, particularly Tornado, the latter brought out by Pavankumar Jain, who wrote in both Gujarati and English. In fact, the cover of ezra 4 with the paper mask was Pavankumar's idea (see Figure 3). He had a wonderful sense of design, whose chief element was disruptiveness, shock. He took playfulness seriously. In the pages of Tornado he would This is a draft version and additional corrections may have been inserted at a later stage. which made Please check the final published manuscript online: $h t t p: / / w w w . t a n d f o n l i n e . c o m / t o c / r j p w 20 / 53 / 1-2$ 


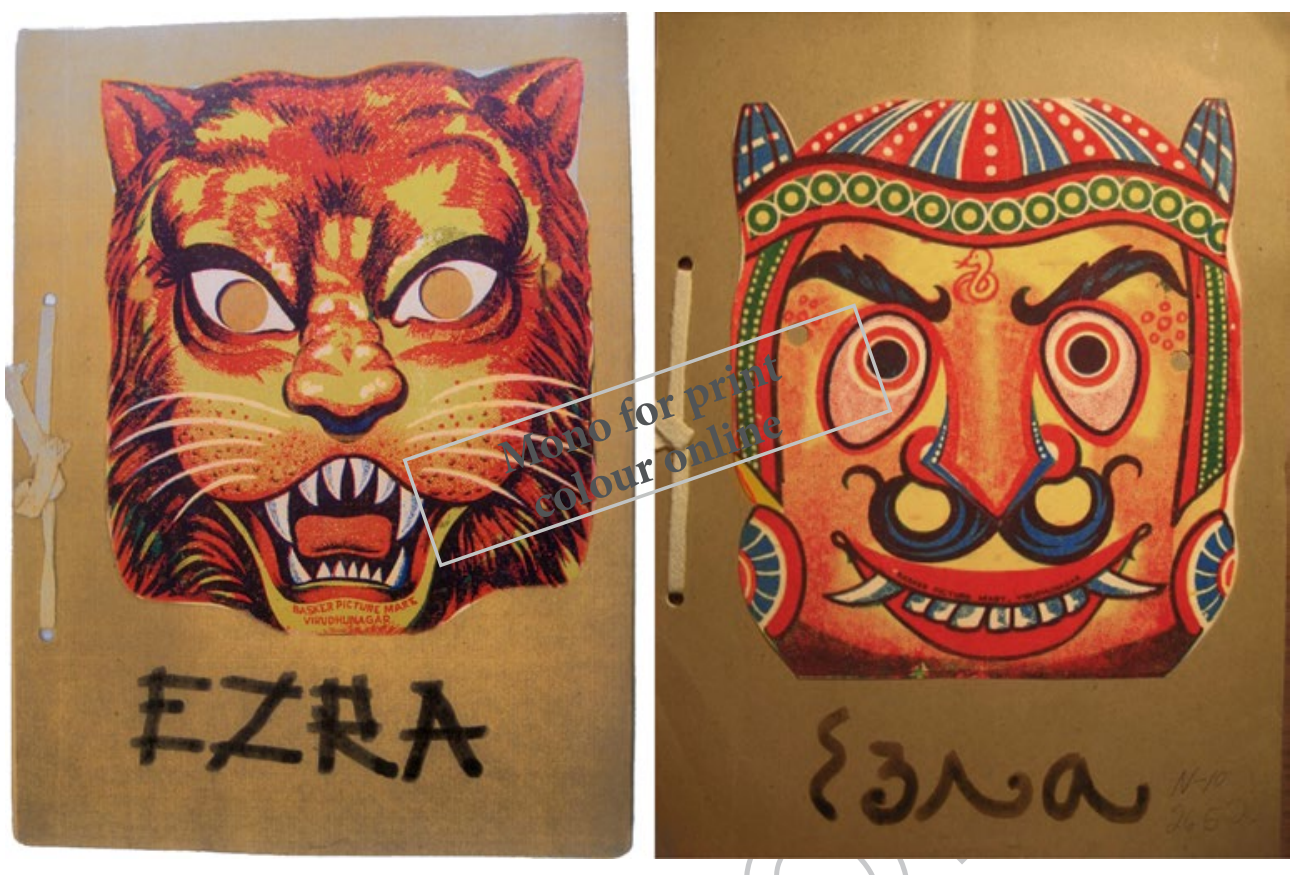

Figure 3. Two covers of ezra 4 (Mehrotra 1968). Mehrotra bought these paper masks from a local toyshop in Allahabad and glued them to the covers, that were all different from each other.

no two copies of the magazine identical. There was also a connection with the Gujarati poets, with Kriti for instance, a Gujarati magazine which had an English section. Then in 1969 you have Vrishchik.

LZ: When I first talked to you about this special issue, you suggested we find someone to write an essay on "Bombay Poets - Baroda Painters". So do you think you could tell us about that connection, and perhaps talk about the importance of Vrishchik, which published so much of your early poetry, and was sometimes illustrated by Bhupen Khakhar and Gulammohammed Sheikh.

AKM: It seems that when one magazine folded another sprang up to take its place. Vrishchik brought poets, painters, translators, art critics on a common platform, but we were there as young rebellious individuals interested in similar things rather than as members of a group. The similarity, I think, had a lot to do with our reverence for the unnoticed and the overlooked, the commonplace and the kitschy. Take Arun [Kolatkar's] "Irani Restaurant Bombay"4 ("the cockeyed shah of iran") and Bhupen's early paintings and you can see the parallels. One of Bhupen's inspirations seems to have been the landscape pictures and portraits often found in Irani restaurants, ${ }^{5}$ but that's not what I mean here. There is in Bhupen's Barber's Shop a Welcome sign - "Wel-come" written in a semicircle - painted on the front glass, which is precisely the kind of detail that Arun would notice too. Its equivalent in "Irani Restaurant" is the cake decomposing "carefully in a cracked showcase". The showcase (without the crack) could have appeared in another of Bhupen's paintings, Janata Watch Repairing, and hung with watches rather than filled with stale cakes. In an early poem of mine in Vrishchik, "Song of the Rolling Earth" (Mehrotra 1970), dated Bombay 1967, there's

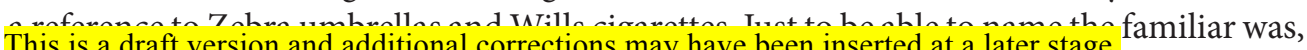
This is a draft version and additional corrections may have been inserted at a later stage.

Please check the final published manuscript online: http://www.tandfonline.com/toc/rjpw20/53/1-2 
for us, to defamiliarize it. We were like cartographers, mapping the city, much as Google Maps does. "Irani Restaurant Bombay" and Janata Watch Repairing, their very names, are like landmarks in the cultural map of the period.

LZ: You also open "Song of the Rolling Earth" (Mehrotra 1970) with a quotation from Apollinaire: "I believe I have found a source of inspiration in prospectuses ... catalogues, posters, advertisements of all sorts".

AKM: This is what I meant, the random everyday things of the street: catalogues, posters, advertisements, signboards.

LZ: And the poetic form of the catalogue, right? You've written about your first encounter with Adil's poetry, and your delight in discovering a poem from Land's End (Jussawalla 1962) which consisted largely of a shopping list.

AKM: I was struck by it because I did not know that a random shopping list could become part of a poem. It is likely that the form of "Song of the Rolling Earth", which is that of a list, came from Adil. This was the break we were trying to make without realizing it. At the same time, if I leave out Nissim, there was little to go against, at least for me. There was no tradition that I was aware of. We almost thought of ourselves as the first poets. So if you are the first poets in a language, where do you start? The Americans gave us a starting point. Could it have been the same for Arun - for the English Arun not the Marathi? Incidentally, we were not the only ones to look towards the Americans. Graziano Krätli has put together the William Carlos Williams-Srinivas Rayaprol correspondence (Krätli forthcoming), where with the very first letter he writes Rayaprol sends Williams two poems, wanting to know if they are any good. "So, what do you say?" he asks. This was in 1949, when Rayaprol was an engineering student in the US. He was 21 years old.

LZ: I had never thought of it that way, that you were writing from what seemed to be a tabula rasa of literature. Now I'm just trying this out ... But was it also about writing on India as if India was any other place? See, I was wondering why you had called one of your little magazines fakir, and also why Douglas Blazek calls you "dr Buddha" in his letters (see Figure 4). As if you were also playing with the clichés about India in the west: the fakirs, the holy cows, the whole "heat and dust" and religious imagery. So was it also about writing about Indian streets as if, say, they were any other street, whether in the US or in Europe?

AKM: Douglas Blazek says in the letter somewhere that he had never written to an Indian before, and the Buddha is what he associated with India. These associations were certainly not in my mind. I called the magazine fakir because I wanted to publish bhakti poetry. ${ }^{6} \mathrm{I}$ had already started doing some Kabir and knew of Arun's Tukaram translations in Poetry India (1966). Dilip too had been translating him. ${ }^{8}$ I would have liked to continue with fakir. At the time, "fakir" did not look like a cliché; at least I was unaware of the exoticizing aspect. The idea that we were living in an exotic place did not even strike us. The literature was too young, and too new, and we were too much on the inside. We were largely writing and translating for ourselves and for each other.

LZ: But you were also sending your poems to American little magazines, weren't you? And there must also have been a form of exhilaration in realizing that you were doing the same stuff as the Americans were, which did not correspond to what they must have expected of Indians. 
dr Buddha--

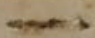

(ah, 1ve always wanted to write to Buddha \& now that this letter is goling to Ind1a to smeon $\mathrm{w} / \mathrm{a}$ Buddha-like name $1 \mathrm{w} 111$ call you Buddha (1 suppose that's just as foolish as wr1ting to me as Jesus, heh?) anyway, fuck religions-- they serve a smazi large but shallow purpose-- oplates of the masses, crutches for the weak, 1 am not concemed w/religion, w/the mystical, w/the mythical, w/communion w1th the gods, the spirits, the creators, the force of energy-- 1 am in-

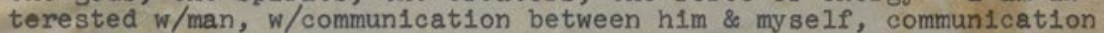
between the world \& myself, communication between myself \& myself. religions are based upons absolutes \& 1 do not believe in absolutes. to me everything is relative, it depends upon personal definition, personal conception, personal truth, personal reality. religions are based on answers while my search in life is based upon questions. 1 do not know any answers, 1 do not know any rest, 1 do not want to sell myself out to any religion, 1 do not want to be conned into any method, plan, law \& religions are just that. ahhh, let me drop this1 may be hitting a sore spot anyway.

befoee 1 forget, why dont you send some of $\mathrm{yr}_{\mathrm{A}} \mathrm{OWn}$ poems to BROWN MILLER / 255 Lakesh1re Dr. / San Franc1sco, Cal1f. / 94015 who is editing a one-shot called LUNG SOCKET. anything goes-- wild, serious, provocative, 1rreverent, caustic, whatever-- no crap or sentimental or dry-turd stuff tho.

havent recelved DAMN YOU/5 yet-- hope $1 t$ gets here considering 1 now have a new address (wh1ch is stamped on the other s1de). you mention that you are thinking of dolng a book which wd justbe a long letter -- that sounds fine, yery much along the lines of what 1 myself am dolng \& what Henry Milier has done. the letter is one of the most natural forms of communication, 1 am surprized more writers havent used 1t-- it has a natural, built, in struiture. It $1 \mathrm{~s}$ a more Immediate \& personal approach as we 1.

dont let this "underground" lowieffopfou. we aje useng $1 t$ only out of lack of having a béfephory of atateng yinat we are try 1 ing to do. 1 usually preface thajlord by GAllio the "so-called" underground but underground is aist to be gidufe w/the "underworld" wh1ch is where the gangsters come in.COfor is it to be confused w/BVERGREEN REVIEW'S "join the unlergreind"-- they are far from the undegground-so far they dont even know what $1 t$ is anymore, altho when they f1rst got started they culled much good materlal frm the underground (which really only means writers or magazines which are small in circulation \& publish material that is not generally acceptable to the masses or even to the falrly advanced ilterary follower simply because it is out of tune $\mathrm{w} /$ what $1 \mathrm{~s}$ taught to be fashionable or correct or good or acceptable, dig?) when they flrst started. there 1 s nothing phony w four asing the world-- we just have to say who we are somehow. we are the outs1ders, the unacceptable ones, the outcasts, the outlars, the lone wolfs, we are of the underground who are trylng to subatogie blank, ster11, worthless, brainwashed minds into thinking more profoundiy, more fecundly, more intelligently, more widely, more gently, more creat1vely. that is the story. that is all there $1 \mathrm{~s}$ to $1 \mathrm{t}$. we ali use words sod that are inadequete-- the dictionary is fuil of thiem. we do not care to live up to this tag-- to be hung by 1 . 1 does not work that way. the word is to function more as a synonym of the unacceptable.

at the moment 1 am flat broke. broke, living in a place that costs more than what we can afford, no furniture, no insurance, no tht nothing. the wife 1 s working while 1 take care of the kids \& write. OPBN SKULL PRESS is dormant unt1l we can save up some bread, split this present domicile, buy a record player, a tape recorder, some furntture \& then some press material to start it running again. It is st1ll alive but $1 t$ w111 be quite a while before $1 t$ swings. have had plenty of bad luck since 1 moved from Illinols to California. 1 have been quite low in spirits, my nerves corkscrewing me-- an old story. my doctor told me that $1 f$ didnt start living w/out depressid \& frustration 1 want last many more yrs. 1 need peace, inner as well as outer. chant for me Arvind. 111 take anything that works! this $1 \mathrm{~s}$ the capitol of the worid for LSD \& other such drugs. Ac1dheads \& freaks walk eyerywhere, how 1 Is LSD \& accepted In Ind1a \& how

\section{Figure 4. Letter from Douglas Blazek to Arvind Krishna Mehrotra, August 20, 1967.}

This is a draft version and additional corrections may have been inserted at a later stage.

Please check the final published manuscript online: http://www.tandfonline.com/toc/rjpw20/53/1-2 
AKM: It's true that the American-mimeographed little magazines published a lot of my early poems. The poems looked American all right: they were in lower case, used little punctuation - all the 1960s mannerisms. Those guys in India are just like us, the Americans would have felt. It also possible that they liked everything that came with an Indian stamp on the envelope!

LZ: Arvind, you told me at the end of our conversation yesterday that you wanted to return to that Apollinaire quotation ...

AKM: The Apollinaire quote actually ties in with the string of quotations on the inside back cover of Pomes, Poemes, Poemas, that Vrishchik brought out as a special issue (Mehrotra 1971). The quotes were from William Blake, Kierkegaard, Mallarmé, Octavio Paz, Breton, Ezra Pound, Dylan Thomas, Yeats, and something from the Chronique des arts. I think what I was trying to do was to create for myself an idea of literature. As you can see, there was no quotation from any Indian work. I was really quite ignorant.

LZ: Were you not also entering into a dialogue with all these writers, placing yourself in a common genealogy?

AKM: Well I suppose so. Creating your own literary ancestors and a context for what you're doing. Perhaps the list Arun makes of the books he was reading from the 1950s to the 1970s could be looked at in the same way. He read in both English and Marathi, but European and American authors far outnumber Marathi ones.

LZ: There's also Lust for Life, Irving Stone's ([1934] 2001) biographical novel about Van Gogh, which Raza and other Indian artists mention as an important book in the 1950s and 1960s, and which also appears in Arun's bibliographical chronology.

AKM: These books provided us with a frame in which to see our work. We were trying to create non-Indian genealogies for ourselves. I mean they were largely non-Indian, not entirely. Which brings me to Amit Chaudhuri's (2008) essay "Poles of Recovery", because the recovery was also taking place.

LZ: If I remember right, he is talking about the twin movements of disownment and recovery, exile and "homecoming" which are characteristic of Indian modernity, and of course you and others were also starting to work on your translations and "recastings" of bhakti poetry in the 1950 s and 1960s.

AKM: There was only one issue of fakir but Vrishchik brought out a medieval poetry number devoted to translations of bhakti poems. ${ }^{9}$ I think what might have attracted us to these poets is what attracted me to the Beats: the outspokenness, the transgression, the free thinking, the upturning of social norms, the use of everyday speech. But to come back to our discussion yesterday; there was something else that we were reading at the time, and that was Jacques Prévert. The Penguin translation, by Ferlinghetti as it happens, was the one we all read (Prévert 1958). A poem in it, "At the Florist's", begins:

A man enters a florist's

and chooses some flowers

the florist wraps up the flowers

the man puts his hand in his pocket

to find the money

the money to pay for the flowers

but at the same time he puts

all of a sudden

his hand to his heart

This is a draft version and additional corrections may have been inserted at a later stage.

Please check the final published manuscript online: http://www.tandfonline.com/toc/rjpw20/53/1-2 
Two decades later, in Bombay, we have another poet who put his hand in his pocket, the "right hand pocket", and that was Arun.

\section{LZ: Saying "My name is Arun Kolatkar"10 ...}

AKM: Why are poets putting their hands in their pockets, one in Paris, the other in Bombay? It is obviously the same hand, the hand of poetry. That's how poetry travels. I am quite certain that Arun would have read this poem, or maybe he hadn't. But something of Prévert's Paroles reaches him anyway. It's the same casual tone, the language stripped bare. What I'm saying is that when you look at the things we were reading at the time, you also start seeing these connections. In the introduction to Paroles, Ferlinghetti quotes a French critic who says that Prévert was the only poet who was able to break through the limits of a specialized public. Prévert is "the voice of the wise street-urchin". All this comes back to me because we were talking about the street yesterday. I'm just trying to get the geography of letters straight...

LZ: I was also thinking about Gulammohamed Sheikh, who talks about devising a painting like "a world sangat" [world assembly] where everyone is free to join. ${ }^{11}$ Hence also the importance of quotations in his paintings. And that leads me to another point I wanted to raise with you, that is the continuing importance of quotations in your own work. It's there in some of your own poetry, in your translations, especially of Kabir, and in your critical essays.

AKM: "World sangat" is a good way of putting it. I think I have an associative mind and read metaphorically. One thing calls up another, and what is called up could be from anywhere, and from any period. Literary texts do not discriminate between themselves; nor should the reader discriminate between them.

LZ: That also reminds me of what you say about Toru Dutt (Mehrotra 2016), and about the globe-encircling strides she made, more than a century ago.

AKM: It does seem that way if you look at the references Toru makes in the notes to $A$ Sheaf Gleaned in French Fields (Dutt 1880). She was, in the 1870s, inviting the world to her table, and delighting in the feast. In the notes you will find Sanskrit seated next to Russian, German next to English. Just before she died at the age of 21 she was trying to get hold of Madame Bovary. That's exactly like us in Bombay waiting for the latest volume of Penguin Modern European Poets to become available in Strand Book Stall. ${ }^{12}$ We all knew Baudelaire but not that Toru had been among the early translators of his work into English. That we had a precursor in her was not revealed to me until quite recently, after the coming of [the] internet, when I was able to read $A$ Sheaf.

LZ: I love what Octavio $\operatorname{Paz}(1992,95)$ says about poetry seeking not immortality but resurrection. Today, it seems that you are the one resurrecting Toru Dutt.

AKM: While Toru's Ancient Ballads and Legends of Hindustan (Dutt 1882) is, for obvious reasons, a cherished part of Indian literature, her translations of Heine out of the French fit no one's idea of what that literature is. A Sheaf should have been seen as a seminal text; instead, in India, it's seen as an aberration at best, if it's seen as anything at all.

\section{LZ: Coming back to the years you spent in Bombay, do you remember your first meeting with Arun?}

AKM: It's in the editor's note to Arun's Collected Poems in English (Kolatkar 2010). Do you have the book here? 
LZ: Yes, give me a minute. Here is the passage:

Sometime in early 1967, in a Colaba Causeway bookshop in Bombay, I first set eyes on Arun Kolatkar. [ ... ] The man in the Causeway bookshop, with his long hair, drooping moustache, large slightly hooded raptorial eyes, and distinctive clothes - five-pocket jeans, round neck t-shirt, white khadi bundi, fitted the image I had of Kolatkar, but before I could gather the courage to walk up to him and introduce myself he was gone. I must have met him soon afterwards, and either on that occasion or later I asked him for a contribution for damn you. He said I should come home with him, and we took a taxi from wherever we were in Flora Fountain to his flat behind the Colaba Post Office, where he lived with his first wife Darshan. It was here, without any fuss, that he gave me the manuscript of "The Boatride", each section on a separate sheet and typed in capital letters, which is how it appeared in damn you 6 in 1968.

AKM: Arun wrote "The Boatride" in 1963 and he could have given it to Quest or to Poetry India, where Nissim I am sure would have gladly published it. But it seems he was waiting for me to turn up. It was his first major poem, the culmination of his early work, and it led directly to Jejuri. That's why he wanted it to be the last poem in The Boatride and Other Poems (Kolatkar 2009). ${ }^{13}$ You can now see the pattern: "The Boatride", followed by Jejuri, Kala Ghoda Poems (Kolatkar 2004a) and Sarpa Satra (Kolatkar 2004b). When I was editing The Boatride and Other Poems, it struck me that I had started out my life as a poet in the 1960s, when one of the things I did was publish "The Boatride" in damn you (see Figure 5). And in 2004 I was editing, at Arun's request, The Boatride and Other Poems. I found this to be a little unsettling. It's as though I'd dedicated my life to Kolatkar's cause. Which in a way I had. And I'd do it again.

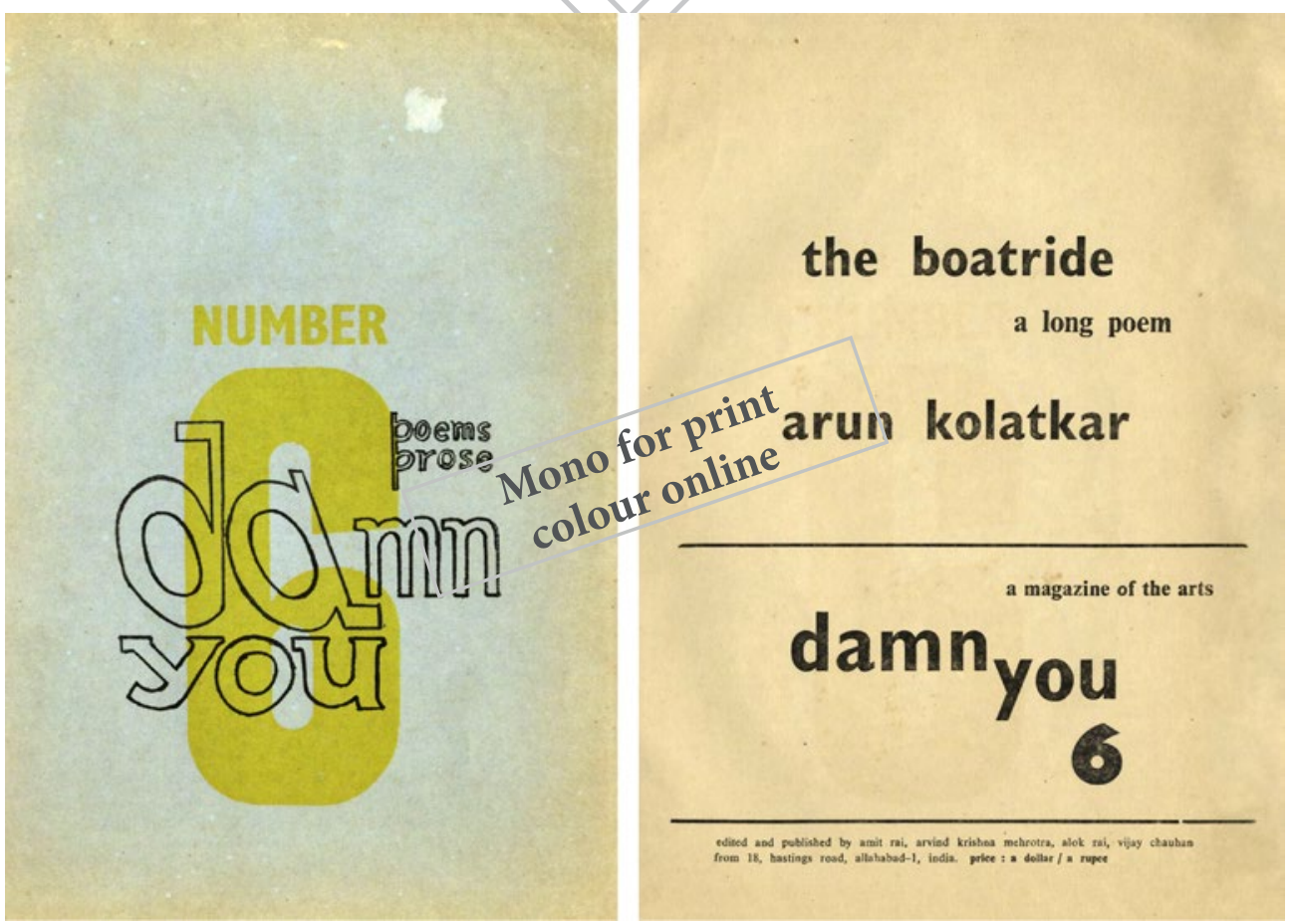

Figure 5. Cover and first inside page with Jejuri title of damn you: a magazine of the arts 6 (Mehrotra, Rai, Rai, and Chauhan 1968).

This is a draft version and additional corrections may have been inserted at a later stage.

Please check the final published manuscript online: http://www.tandfonline.com/toc/rjpw20/53/1-2 
LZ: It seems that Kolatkar is a constant presence in your life and in your work, especially in your essays where you keep going back to him, as if Arun was finding a way in everything you wrote, as if the conversation with him was still going on.

AKM: You are so right. I've often thought about this myself. When I look at some of the books on my shelves, I often find I've written "Jejuri" or "Kolatkar" in the margin. One is constantly being reminded of Arun, of his poems or of something he said in an interview. As a consequence, there is hardly an essay of mine that does not bring in Kolatkar in some form or other.

LZ: This close bond with Arun and with Adil is really remarkable. You've exchanged hundreds of letters, dedicated your collections to each other, reread each other's manuscripts. But that fraternity also extended outside Bombay, to Ramanujan for instance, who read and commented on your first version of The Absent Traveller. I wonder if you could reflect on the ways these friendships allowed you to write.

AKM: The dialogue with Ramanujan still continues in the silent manner in which these dialogues are conducted. And Arun was having his own dialogue with him. Remember the line from "Making Love to a Poem": "Will the real Ramanujan please stand up" (Kolatkar 2009, 354)? Arun and I would talk about Ramanujan sometimes. I was reading Ramanujan again recently, because Adil told me that he was reading Sartre's book on Baudelaire. There seems to be no connection between the two, between me reading Ramanujan and Adil reading Sartre, but there is. It so happened that I had the book that Adil was reading and in it Sartre talks about Baudelaire's self-consciousness. He says Baudelaire never forgot himself but "watched in order to see himself watch". Now throughout Ramanujan's (1986) Second Sight there are references to watchers. One of the poems has an epigraph from the Mundaka Upanishad: "Two birds on the self same tree: one of them eats the fruit of the tree, and the other watches without eating". I wondered how Sartre could have said this about Baudelaire without reading the Mundaka first. It says exactly the same thing. One is constantly making these discoveries through reading and through our conversations with each other. Sartre's insight into Baudelaire could quite profitably be used to read Ramanujan.

LZ: And perhaps this tight fraternity compensated for the indifference of your surroundings, the "culture of shortages" that you or Adil have talked about, what you said at the beginning of our conversation about having the feeling of writing when there was no literary tradition to belong to.

AKM: This fraternity is what made poetry possible, at least for me. Even today, anything that Adil reads he shares, and I do the same. What I am trying to say is that the dialogue hasn't ended, neither with the living nor with the dead.

LZ: The dialogue with the heaven where all good poets go. Remember Kolatkar's wonderful lines: "i write for their combined eye the collective ear heine blake mandelstam apollinaire Baudelaire ... ". ${ }^{14}$

AKM: And now Ramanujan and Kolatkar have joined their combined eye the collective ear. 


\section{Notes}

1. A long poem that Arvind Krishna Mehrotra first published in mimeographed form.

2. The magazine Quest, "A Bi-monthly of Arts and Ideas", sponsored by the Indian Committee for Cultural Freedom and edited by Nissim Ezekiel, was one of the most influential Englishlanguage magazines devoted to cultural, literary and political matters in post-Independence India. See Graziano Krätli's article in this special issue of "The Worlds of Bombay Poetry".

3. See the interview with Adil Jussawalla in this issue of the Journal of Postcolonial Writing.

4. See this issue of the Journal of Postcolonial Writing for Vinay Dharwadker's translation of Arun Kolatkar's poem ("Irani Restaurant") from Marathi into English.

5. See the opening text of this special issue of the Journal of Postcolonial Writing (Arun Khopkar's essay "Footloose and Fancy-free in Bombay: A Partial View of the 1960s and 1970s") for an evocation of the Irani restaurants of Bombay.

6. Many different forms of medieval devotionality are known as bhakti, which first emerged in South India around the 6th century before spreading to the rest of India. Bhakti represented a compelling and non-exclusive movement of popular devotion, which included men and women from all castes, classes and stages of life. Bhakti "poets" such as Tukaram, Namdev or Jnandev from the Marathi tradition, or the 15th-century Kabir from North India rejected Sanskrit in order to produce extraordinary compositions and devotional songs in the vernaculars.

7. The remarkable first issue of the journal Poetry India (Ezekiel 1966) included translations of Vedic hymns from Sanskrit by P. Lal, translations of Tamil classical love poetry by A.K. Ramanujan, Marathi translations of Mardhekar by Dilip Chitre and of Tukaram by Arun Kolatkar.

8. Dilip Chitre's translations of Tukaram later appeared in book form (Chitre 1991).

9. See Gulammohammed Sheikh's interview in this special issue of the Journal of Postcolonial Writing.

10. Reference to a poem by Arun Kolatkar: "My name is Arun Kolatkar/I had a little matchbox/I lost it/then I found it/I kept it/in my right hand pocket/It is still there" (Kolatkar 2010).

11. See Gulammohammed Sheikhs interview in this special issue of the Journal of Postcolonial Writing.

12. One of the most iconic bookshops of Bombay. See Arun Khopkar's opening essay of this special issue of the Journal of Postcolonial Writing for an evocation of Strand.

13. The Boatride and Other Poems (Kolatkar 2009), edited by Arvind Krishna Mehrotra and brought out by Ashok Shahane's Pras Prakashan, draws on uncollected and unpublished poems by Arun Kolatkar, and was published posthumously.

14. Part of Kolatkar's unpublished papers. Quoted in Zecchini $(2014,72)$.

\section{Disclosure statement}

No potential conflict of interest was reported by the author.

\section{Notes on contributor}

Laetitia Zecchini is a research fellow at the CNRS in Paris, France. Her research interests include contemporary Indian poetry, the politics of literature, postcolonial criticism and issues of modernism and cosmopolitanism. She has co-translated Arun Kolatkar and Kedarnath Singh into French, and is the author of Arun Kolatkar and Literary Modernism in India, Moving Lines (2014), which aims at telling $a$ story of modernism in India through a particular poet, Arun Kolatkar, and a particular time and place, the ebullient post-Independent Bombay scene from which his poetry is inseparable. She recently co-edited two journal issues (for the Revue de littérature comparée, 2015 and for Littérature, 2016) on questions of Indian literary history, and is starting a collaborative project on writers' organizations, free speech and the All-India PEN Center.

This is a draft version and additional corrections may have been inserted at a later stage. Please check the final published manuscript online: http://www.tandfonline.com/toc/rjpw20/53/1-2 


\section{References}

Chaudhuri, Amit. 2008. "Poles of Recovery." In Clearing a Space: Reflections on India, Literature and Culture, 39-57. New Delhi: Permanent Black.

Chitre, Dilip, ed. 1991. Says Tuka: Selected Poems of Tukaram. New Delhi: Penguin Books India.

Dutt, Toru. 1880. A Sheaf Gleaned in French Fields. London: Kegan Paul.

Dutt, Toru. 1882. Ancient Ballads and Legends of Hindustan. London: Kegan Paul.

Ezekiel, Nissim, ed. 1966. Poetry India 1 (1-6). Bombay: Paricay Trust.

Ezekiel, Nissim. 2005. Collected Poems 1952-88. New Delhi: Oxford University Press.

Ferlinghetti, Lawrence, Allen Ginsberg, and Gregory Corso. 1963. Penguin Modern Poets 5. Harmondsworth: Penguin.

Jussawalla, Adil. 1962. Land's End. Calcutta: Writers' Workshop.

Jussawalla, Adil, ed. 1974. New Writing in India. Delhi: Penguin Books.

Jussawalla, Adil. 1976. Missing Person. Bombay: Clearing House.

Kohli, Devindra, ed. 1991. Indian Writers at Work. Delhi: B.R. Publishing Corporation.

Kolatkar, Arun. 2004a. Kala Ghoda Poems. Mumbai: Pras Prakashan.

Kolatkar, Arun. 2004b. Sarpa Satra. Mumbai: Pras Prakashan.

Kolatkar, Arun. 2009. The Boatride and Other Poems. Edited by Arvind Krishna Mehrotra. Mumbai: Pras Prakashan.

Kolatkar, Arun. 2010. Collected Poems in English. Edited by Arvind Krishna Mehrotra. Tarset, Northumberland: Bloodaxe Books.

Krätli, Graziano, ed. Forthcoming. Why Should I Write a Poem Now: The Letters of Srinivas Rayaprol and William Carlos Williams, 1949-1958. Albuquerque, NM: University of New Mexico Press.

Mehrotra, Arvind Krishna. 1966. Bharatmata: A Prayer. Bombay: Ezra-Fakir Press.

Mehrotra, Arvind Krishna, ed. 1967. ezra: an imagiste magazine, 1.

Mehrotra, Arvind Krishna. 1970. "Song of the Rolling Earth." Vrishchik 1: 9-10.

Mehrotra, Arvind Krishna. 1971. Pomes, Poemes, Poemas. Baroda: Vrishchik.

Mehrotra, Arvind Krishna, ed. 1991. The Absent Traveller: Prakrit Love Poetry from the Gaathaasaptashatii of Saavahanan Haala. Translated by Arvind Krishna Mehrotra. New Delhi: Ravi Dayal.

Mehrotra, Arvind Krishna, ed. 1992. The Oxford India Anthology of Twelve Modern Indian Poets. New Delhi: Oxford University Press.

Mehrotra, Arvind Krishna, ed. 2003. A History of Indian Literature in English. New York: Columbia University Press.

Mehrotra, Arvind Krishna. 2011. Songs of Kabir. New York: New York Review Books Classics.

Mehrotra, Arvind Krishna. 2012. Partial Recall: Essays on Literature and Literary History. Ranikhet: Permanent Black.

Mehrotra, Arvind Krishna. 2014. Collected Poems 1969-2014. New Delhi: Penguin India.

Mehrotra, Arvind Krishna. 2016. “Toru Dutt and an Eurasian Poet." In A History of Indian Poetry in English, edited by Rosinka Chaudhuri, 114-129. New York: Cambridge University Press.

Mehrotra, Arvind Krishna, Amit Rai, Alok Rai, and Vijay Chauhan, eds. 1968. damn you: a magazine of the arts 6. Allahabad: MehRotra, Rai, Rai and Chauhan.

Parikh, Prabodh. (1996) 2006. “Homecomings.” Poetry International Rotterdam, June 1. http://www. poetryinternationalweb.net/pi/site/cou_article/item/6769.

Patel, Gieve. 1966. Poems. Bombay: Nissim Ezekiel.

Paz, Octavio. 1992. The Other Voice: Essays on Modern Poetry. New York: Harcourt Brace Jovanovich. Prévert, Jacques. 1958. Paroles. Translated by Lawrence Ferlinghetti. San Francisco: City Lights Books.

Ramanujan, A. K. 1986. Second Sight. New York: Oxford University Press.

Stone, Irving. (1934) 2001. Lust for Life. London: Arrow Books.

Zecchini, Laetitia. 2014. Arun Kolatkar and Literary Modernism in India: Moving Lines. London, New Delhi, New York: Bloomsbury. 